\title{
REFLEXIÓ
}

\section{Dános Valér}

\section{A tökéletlen tökéletesség avagy a Rendészettudományi szaklexikonnal kapcsolatos reflexiók margójára}

\author{
The unperfect perfectness, \\ or remarks to reflections in connection \\ with the Law Enforcement Lexicon
}

„Ahhoz, hogy az ember valami egész újat meglásson,
ahhoz egész másképp kell gondolkodni. És ha az ember
másképp gondolkodik, azt mondják, hogy bolond."
Szent-Györgyi Albert

\begin{abstract}
Absztrakt
Mint a Rendészettudományi szaklexikon egyik lektora, szakmai meggyőződéssel vallom, hogy a tinédzserkorába lépő rendészettudományunk területén müfajtörténeti jelentőségü alkotás született e lexikon megjelentetésével. Azt is szeretném rögtön a reflexióm elején leszögezni, hogy se nem dicsérni, se nem temetni jöttem ezt a gigantikus kiadványt. Írásomban igyekszem a tárgyilagosság, az objektivitás és a semlegesség talaján maradni még azzal együtt is, hogy a bevezetö mondatban határozott elismerésemnek adtam hangot. Az elismerés mögött - szándékom szerint - valójában köszönet áll. Köszönetemet kell tehát kifejeznem azért, amiért a szerzők és a szerkesztők megajándékozták a rendészettudomány művelőit, e tudomány iránt érdeklődőket, a szélesebb olvasói közvéleményt ezzel a mai rendészettudományi kultúrának megfelelő mủvel.
\end{abstract}

Kulcsszavak: rendészettudomány, szaklexikon, reflexió 


\begin{abstract}
As one of the peer reviewers of the Law Enforcement Lexicon I state with full professional conviction that publication of this lexicon created a work of genre-historical importance for our law enforcement science reaching its teenage years. I would also like to record at the beginning of my reflection that I want neither praise nor blame this gigantic publication. In my notice I intend to stay impartial, objective and neutral even though I expressed my definitive recognition in the introducing sentence. This recognition means, according to my intention, rather thanks. So, I have to thank for the authors and editors as they gave a present to active contributors of law enforcement science, for people interested in it and for a wider reader public by this work appropriate to the present level of our law enforcement culture.
\end{abstract}

Keyword: law enforcement science, specialist lexicon, reflection

Korinek László, aki maga is elismeri, hogy a lexikon „mérföldkő, mely sok jószándékú szakember közös erőfeszitéseként, hosszú évek munkája után született meg" (Korinek, 2020, 8.), az Utószó a Rendészettudományi szaklexikonhoz címü cikkében lenyügöző módon, utánozhatatlan pedagógiai érzékkel forgalmazza meg kritikai észrevételeit, tagadva azok „hibajegyzék” voltát (Korinek, 2020, 8.). Magam az MTA kandidátusi aspirantúrámat anno az MTA Jogtudományi Intézetében folytattam, és tudományos vezetőm az a Szabó András professzor volt, aki mesterfokon volt képes még a legzordabb intelmeit is segítő szándékú, építő jellegü kritikaként megfogalmazni a tanítványai felé, többnyire kellő díszcsomagolásba burkolva. Mert mesteremnek az ilyen zord kritikai megjegyzéseit következetesen megelőzte, majd aztán követte az elismerő buksisimogatás. De, ami a két buksisimogatás között elhangzott, az szinte egyenlöt jelentett a morzsolt kukoricára térdelés szankciójával. Nos, valami ilyesmit éreztem újra Korinek László reflektív cikkének elolvasása közben, de még inkább elolvasása után. Beregnyei József, a lexikon vezető szerkesztője azonban észre vehette ezt a pedagógiai fogást, és bátran megszabadította Korinek pakkját a díszes csomagolópapírtól, és elsősorban profeszszor úr kritikai megjegyzéseire reflektált a folyóirat 2021. januári számában megjelent Egy „Elöszó” utáni „Utószó” -ra történő reflexió ” címü cikkében (Beregnyei, 2021, 143-149.).

De miért is ragadhatott azon nyomban Beregnyei József tollat Korinek László cikkének elolvasása után? Feltételezem azért, amiért én is igyekeztem gyorsan reagálni a két észrevételre. Mint tudjuk, elsőknek lenni jó. Jó, mert 
az utána következőket az elsőként elhangzottak nagy mértékben befolyásolják, mi több orientálják véleményük és mondanivalójuk kialakításában. Be kell vallanom, engem is nagymértékben befolyásol Korinek és Beregnyei cikke, nem tudok, de nem is akarok megszabadulni a cikkek torokszorító szoros kötelékeitől. És ami a legfontosabb, nem szándékozom élni a díszes csomagolás trükkjével, ellenkezőleg, a hivatkozott két cikkel kapcsolatos realista reflexiómat kívánom megosztani az olvasókkal.

Nem csupán elfogadni tudom, sőt abszolút mértékben azonosulni is tudok Korinek szellemes hasonlatával, amikor cikkének rögtön az elején palackpostaként aposztrofálja a lexikont: „...ezt a nagyterjedelmü munkát palackpostának neveztem”. (Korinek 2020, 8.). Magam is palackpostának gondolom e nagyterjedelmü müvet, amely komoly üzenetet cipel magával. Palackposta, de szerencsére semmi esetre sem időkapszulába zárt mü, különösen nem évekre, évtizedekre lezárt időkapszulába zárt alkotás. Néhány sorral odébb pedig Korinek írásának okaként egy churchilli idézetet használ: „...'ugródeszkaként és ne diványként'tekintsünk a múltunkra". (Korinek, 2020, 8.). Paradoxonnak tủnhet, hogy e két párhuzamosan futó idézetet én már a végtelen előtt találkozásra kényszerítem. Sőt, találkozásra kényszerítem a harmadik párhuzamosan utánuk szaladó idézetet: „,... tekintsünk rá úgy, hogy elkészült a földszint, de folyamatosan munkálkodni kell, hogy a mi nemzedékünk egy olyan épületet adjon át a következö generációnak, amitöl kötelességüknek érzik majd, hogy tovább magasitsák”. (Korinek, 2020, 8.). Hogy miért hívom e három idézetet egy közös találkozásra? Mert mindegyikben van egy közös pont, ez pedig nem más, mint a jövőre való utalás. A palackpostával a jövőnek szoktunk üzenni. A dívány említése is arra utal, hogy szerzők ne pihenjetek le, mint akik már befejezték a nagy művet, hanem folytassátok a megkezdett munkát. Végül a földszint magasítása sem a mai, hanem az eljövendő idők feladatának tekinthető ebben az összefüggésben.

Miként is reagál mind erre Beregnyei József? Messze nem tekinti lezárt „ügynek” a lexikon megjelenését, sőt: „Azt nem gondolom, hogy már most szükség volna a javasolt átdolgozásra, de azt tudom, abban biztos vagyok, hogy ezt a munkát - ahogy ö is írja (mármint Korinek - a szerző) - tovább kell végezni, a végterméket szükséges utógondozni ...” (Beregnyei, 2021, 147.). Én is szeretném hinni, hogy ezt a palackpostát a szerzők és a szerkesztők szánt szándékkal nem zárták le véglegesen, és nem kívánnak megpihenni a churchilli díványon, legfeljebb a díványhoz tartozó fotelba ülni, és tenni majd a dolgukat. Abban is reménykedem, hogy a szerzők nem gondolják úgy, hogy csupán a földszint megépítéséig jutottak el, hanem - szándékukkal megegyezően - egy kulcsrakész épületet adtak az olvasók kezébe. Lektori munkám 
során, illetve a lexikon átnézése után, én e müvet - Korinekkel ellentétben egy kulcsrakész, stabil falakkal rendelkezö, többemeletes alkotásnak tekintettem, illetve tekintem, nem pedig csupán egy földszintes építménynek. Lektori véleményemben ezért is támogattam a mielöbbi megjelentetését. Jól tudjuk, hogy egy kulcsrakész építmény átadásának általában velejárója a garanciális utómunkálatok jegyzékbe foglalása, majd a hiányosságok pótlása, az esztétikai hibák kijavítása. De ettől még lakható, mi több, élvezhető is lehet az épület. Én mindenképpen annak tekintem azzal együtt, hogy még hátravan annak a hibajegyzéknek az elkészítése is, amely hozzásegíti a szerzőket a garanciális munkálatok mielőbbi elvégzéséhez. Beregnyei maga is számít a sok jóindulatú észrevételre, építő jellegü kritikák megfogalmazására, amikor azt írja, hogy elfogadja azokat $a, \ldots$ kritikai és épitö jellegü észrevételeit, javaslatait is, amelyeket a majdani szerkesztőség szerintem figyelembe fog venni a második kiadásban ....” (Beregnyei, 2021, 147.), amelyre „,...5-10 éven belül egyébként is sort kell keriteni." (Beregnyei, 2021, 147.). A korábbiakban általam említett „garanciális hibák” kijavítása igencsak jelentős feladatot ró a majdani szerkesztőkre, emellett azonban a fiatal rendészettudomány is újabb és újabb ismeretekkel, tudományos eredményekkel fog gazdagodni. El tudom fogadni Beregnyeinek azt a vélekedését, hogy a második kiadásra még 5-10 évet várni kell. Azt azonban már nem, hogy a „garanciális hibák” kijavításával is várjunk egy évtizedet. A megoldást maga Beregnyei szolgáltatja az új digitális világrendbe illeszkedő felvetésével: „,...célszerü utólag egy online (digitális) változatot - lásd: Magyar Néprajzi Lexikon, Magyar Katolikus Lexikon - is elkésziteni." (Beregnyei, 2021, 148.). Véleményem szerint a már kialakult digitális világrend nem csupán lehetővé teszi a print változat mellett az elektronikus (digitális) forma mielőbbi elkészítését, hanem egyenesen kiköveteli magának. Ez a munka lényegileg nem több, mint egy pdf formátummá történő átalakítás, és egy újratördelés. Előnye viszont óriási, könnyebben olvashatóvá, illetve kereshetővé válnak az egyes szócikkek.

Amint az érzékelhető az előző gondolatok megfogalmazásából, igazi gondom e tekintetben nekem csupán az időbeliséggel van, nevezetesen a múltidö, a jelenidő és a jövőidő fura találkozásával. Korinek a cikkében arról ír, hogy „,... folyamatosan munkálkodni kell, hogy a mi nemzedékünk olyan épületet adjon át a következö generációnak .....”, majd arrébb ez olvasható: ,, a lexikont tanulmányozva egyre határozottabban azt érzem, hogy ez a palackposta nem a 21. század, hanem a 19. század üzenete.” (Korinek, 2020, 8.). Ugyancsak az igeidők egymásra épülése jelenik meg a következő mondatában: „, ... a húszéves 21. század az elkövetkezendö évtizedek polgárai, rendészeti szakemberei és a rendészetet kutató utódok számára üzen.". (Korinek, 2020, 8.). 
Én a lexikont tanulmányozva viszont azt érzem, hogy a palackpostával a rendészettudomány mai kutatói - helyesen - a jelen és a jövő tudósainak, kutatóinak, érdeklődőinek üzennek - a jelen ismeretrendszeréről. Nem gondolhatták ezt másként a szerkesztők sem, hiszen erre utal Beregnyei következő megjegyzése is: ,....nehéznek bizonyult, hogy a jelenben beszéljünk (irjunk) a jövőnek, úgy, hogy tekintettel legyünk a múltra, a történelmi észrevételekre is. " (Beregnyei, 2021, 146.). A múltat, legalábbis véleményem szerint, ne kérjük számon egy lexikontól, azt inkább hagyjuk nyugodtan az enciklopédiákra.

Apropó! Enciklopédia. Korinek a cikkében több helyen felrója a szerzőknek, hogy hiányoznak a nagy elődök gondolatai, elméletei, továbbá a klasszikusokból történő merítés (lásd Finszter Géza vagy Szikinger István monográfiáját). Ezzel Korinek végül is azt kéri számon a szerkesztőktől, hogy miért nem enciklopédia született, a lexikon helyett. A Finszter és Szikinger hivatkozások véleményem szerint inkább monográfiákba, tanulmányokba vagy enciklopédiákba valók, mintsem lexikonba. Hasonló módon gondolkodhattak a szerkesztők, amire a következő Beregnyei mondatok is utalnak: „Fontosnak tartom, hogy egy szaklexikont kissé más módon kell megközeliteni, nem úgy és mint egy egyetemi jegyzetet, egy tudományos jellegü cikket vagy egy konferencián elhangzó vitainditót. Meggyözödésem szerint egy szaklexikonban nem lehet nagyterjedelmü eszmefuttatásokat megengedni." (Beregnyei, 2021, 145.). Hiszem, hogy igaza van.

Jól lehet ma már a lexikonok és az enciklopédiák között nincs olyan éles határ, mint korábban volt, én azonban a müfajtörténeti hüség miatt szívesen teszek különbséget a két fogalom között. Ebben az értelemben az enciklopédia címszavai inkább általános összefüggéseket, részleteket dolgoznak fel, és a címszavakat rövidebb-hosszabb magyarázatok, kifejtő szövegek is követik. A lexikon címszavai viszont egy-egy fogalom definíciója mellett esetenként csupán kisebb terjedelmü, rövid magyarázatot adnak, amelyeket a szerzők szigorú betürendbe szerveznek. A Rendészettudományi szaklexikon címet viselő alkotás címszavai alatt megtalálható tartalmak viszont nagy többségében a klasszikus lexikoni megoldást tükrözik, és bár előfordul számos helyen öszszefüggéseket, magyarázatokat tartalmazó igencsak rövid eszmei futtatás, ettől még a mü nem válik enciklopédiává. Az pedig, hogy keveredik a lexikonban a két müfajbeli megoldás, az manapság már nem bün, függetlenül attól, hogy nekem nem tetszik. E gondolatok után már okszerüen következik az, hogy nem tudom elfogadni Korineknek azt a véleményét, hogy „A szaklexikon feladata a tudományos nézetek bemutatása, a viták felvillantása." (Korinek, 2020, 15.). Majd odébb: „Ilyen szerkesztési filozófia mellett az sem baj, ha egy-egy ismertetés akár többoldalt is elfoglal a lexikonban." (Korinek, 2020, 15.). 
Ugyanakkor szívesen látnék az elméleti szakemberek részéről elkészítendő, a klasszikus felfogás szerinti enciklopédiát, mondjuk Rendészettudományi enciklopédia címmel, amelyben helyt kaphatnak a „,tudományos nézetek bemutatása, a viták felvillantása." (Korinek. 2020, 15.). Ugyanakkor tiszteletben tartom másoknak az enyémtől eltérő véleményét a szaklexikonok és a szakenciklopédiák küldetésének értelmezéséről, így Korinekét is, amikor a Rendészettudományi szaklexikon szerzőit rendészeti enciklopédistáknak nevezi: „...a rendészeti enciklopédisták csapatát arra biztassam, legyenek büszkék elért eredményeikre..." (Korinek 2020,16.). Azt csak halkan jegyzem meg, hogy egy lexikon esetében nem hiba, ha nem csupán az elméleti szakemberekhez, hanem a végrehajtásban dolgozó szakemberekhez, az oktatásban részvevőkhöz is szól a lexikon. Ez különösen érvényes a rendészettudomány területére, ahol az elméleti rendészettudomány mellett már megjelent és lassan elfogadottá is vált az alkalmazott rendészettudomány. Tegyük hozzá: szerencsére! Ennek folyományaként egy Kossuth Lajos idézet jut eszembe: „Be kell vinni az életet a tudományba, hogy a tudományt kivihessük az életbe."(URL1). A lexikonban találkozunk számos olyan - mind tartalmilag, mind grammatikailag - helytelen megfogalmazással, helytelen meghatározással, amire Korinek felfigyelt, és Beregnyei is el tud fogadni. Korinek reflexiójában jó néhány - élesebb kritikai - minősítést is megfogalmaz, amelyeket Beregnyei nemes önmérséklettel fogad és próbál megmagyarázni. Ilyenek a szolgálati szabályzatszerű megfogalmazás, a silány, a gyáva, a félrevezető, a kincstári kifejezések, az igénytelen megfogalmazás, a morális probléma kifejezések, jelzők. Amennyiben ezeket a kritikai megjegyzéseket, jelzős szerkezeteket a maguk helyén, az adott szövegkörnyezetben értelmezzük, már korántsem annyira udvariatlanság sem a tudománnyal, sem a szerzőkkel szemben. Ezek mind helytállóak, és valóban létező hiányosságai a lexikonnak. És hogy miként reagál mind erre Beregnyei a reflexiójában? Előre bocsátom, hogy a silány, a gyáva jelzőt nem tudom miért húzza magára Beregnyei, holott Korinek a tudományossággal általános összefüggésben és nem konkrét szócikkel vagy szócikkekkel kapcsolatban említi. Ezzel kapcsolatban Beregnyei megjegyzi: „,... ami esetünkben a gyáva jelzőhöz kapcsolódik, igen, elismerem valószinüleg túlzottan is óvatosak voltunk." (Beregnyei, 2021, 146.). Az pedig pláne nem mentség, hogy Beregnyei magyarázatként az említett további jelzőkkel összefüggésben így érvel: „,... a munkálatokat .... eltérö képességü és szaktudású közremüködök végezték...”, ,, .. a vállalás teljesitésének a határideje és a terjedelme is behatárolt volt." (Beregnyei, 2021, 145.).

Korinek kifogásolja a „harcparancs” szócikk felvételét a lexikonba: „,Mindenek elött kifogásolható, hogy a címben megjelölt tudományterületen 
túlmutató definíciók is megjelennek a kötetben. ... Mivel azonban mégiscsak egy közigazgatási tevékenységhez kapcsolódó fogalomrendszerröl van szó, ezért egyenesen félrevezetönek tartom az olyan címszavak beiktatását, mint például a harcparancs..." (Korinek, 2020, 14.). Beregnyei kellő tisztelettel ugyan ismét megmagyarázza a szócikk felvételének indítékát: „Ez is példa lehet arra, amivel korábban a rendészet kutatói - többek között Finszter Géza professzor is - rávilágitottak a rendörség és a katonaság, illetve a rendészet és a honvédelem közötti különbségekre, és ehhez képest - nemcsak a jelenlegi veszélyhelyzetre tekintettel - mást tapasztalhatunk napjainkban a Honvédség, a honvédek igénybevételére vonatkozóan." (Beregnyei, 2021, 147.). De az érvelése további kifejtésre, érvelésre szorulna, már csak a honvédelmi és a rendvédelmi szervek egyre szorosabb munkakapcsolatára figyelemmel.

Végezetül, nem beleesve a „buksisimogatás” csapdájába, soraimat azzal zárom: bízom benne, hogy a lexikont olvasó, forgató rendészettudományi kollégák is osztják a lexikon kulcsrakész jellegét, legalább annyira, mint a szerzők, a szerkesztők, a lektorok és természetesen jómagam. A garanciális munkák elvégzéséhez és az utógondozáshoz pedig erős hitet és kitartást kívánok e munkálatokban résztvevőknek.

PS: Bevallom őszintén, a cikk elejére írt Szent-Györgyi Albert idézettel magam gyakran szembesültem és szembesülök manapság is.

\section{Felhasznált irodalom}

Beregnyei J. (2021): Egy „Előszó” utáni „Utószó”-ra történő reflexió. Belügyi Szemle, 69(1), 143-149.

Korinek L. (2020). Utószó a Rendészettudományi szaklexikonhoz. Belügyi Szemle, 68(11), 7-17.

\section{A cikkben található online hivatkozások}

URL1: CITATUM. https://www.citatum.hu/idezet/90790

\section{A cikk APA szabály szerinti hivatkozása}

Dános V. (2020). A TÖKÉLETLEN TÖKÉLETESSÉG, avagy a Rendészettudományi Lexikonnal kapcsolatos reflexiók margójára. Belügyi Szemle, 69 (2), 321-327. https://doi.org/10.38146/ BSZ.2021.2.9 